\title{
Prefatory chapter: Institutions and social innovation
}

\section{W. Richard Scott}

Institutions again matter! After decades of denial, oversight and misspecification - under labels varying from behaviorism to individualism to neoclassical economics extending for many decades well into the twentieth century - social scientists have rediscovered the pivotal role played by institutions in social life. Institutional arguments are once again being formulated across the social sciences - by anthropologists, economists, social historians, management scholars, political scientists and sociologists. Coase, Commons, Durkheim, Marx, Weber and Veblen are again being read and their insights reclaimed and renewed. And institutional approaches are being crafted to examine social processes and structures across a full spectrum of levels of analysis ranging from games and groups to organizations, organizational populations, organizational fields, sectors, societies and transnational systems.

While the reach of institutions is wide, in the last two decades interest and research attention have been concentrated at more macro levels. Fueled by globalization fever, much attention has been devoted to rapidly increasing levels of international trade and economic interdependence. Seemingly, everyone is talking about globalization. Some accounts imply that we are all trapped on a 'run-away world' - that we are unwilling passengers on 'a very fast train without drivers' fueled by market forces, weakening state boundaries and technological breakthroughs. Everyone is not wrong. We inhabit an increasingly interdependent planet, but one I, together with the editors and contributors to this volume, believe is amenable to analysis and to intervention.

As Guillén (2001b) reminds us, globalization forces have been at work for a long time, and our own efforts are only the most recent in a long series of attempts to develop useful conceptual frameworks for interpreting and attempting to guide modernization and globalization processes. Influential previous approaches include modernization theory (Rostow, 1960), dependence theory (Evans, 1979), world systems theory (Wallerstein, 1974), late-industrialization arguments (Gerschenkron, 1962) and neoclassical 
approaches (Leff, 1978). Compared to these earlier perspectives, current institutional approaches ${ }^{1}$ offer a number of important advantages:

- They eschew a 'totalistic' or monolithic view of modernization processes and economic development.

- They encourage detailed attention to the specifics of institutional variety at the organization, sector or societal levels. ${ }^{2}$

- They support attention to the complex interactions among institutional processes at multiple levels.

- They recognize that the globalization processes now under way not only conduce to areas in which structures and activities converge, but also promote diversity and innovation.

\section{INSTITUTIONAL ELEMENTS}

Contemporary or neoinstitutional theory got under way in the 1970s, with the work of Berger and Luckmann (1967), DiMaggio and Powell (1983), Hall (1986), March and Olsen (1984), Meyer and Rowan (1977), Meyer and Scott (1983), Moe (1984) and Williamson (1975) leading the way. A flood of theoretical advances informed by a wide range of empirical studies have followed since then and up to the present time, making institutional theory one of the most lively intellectual arenas within the social sciences (see Scott, forthcoming). While there is clear maturation and progress, as of this time there remain many and varied conceptions of institutions - for a sampling, see Bourdieu and Wacquant (1992), Campbell (2004), Hall and Soskice (2001), Nee (2005), North (1990, 2005), Ostrom (1990), Peters (1999) and Pierson (2004). It will not come as a surprise that I prefer my own conception of institution:

Institutions are social structures that have attained a high degree of resilience [and are] composed of cultural-cognitive, normative, and regulative elements that, together with associated activities and resources, provide stability and meaning to social life. (Scott, 2001: 48)

Fortunately for current purposes, this conception has been generally embraced by the editors of this volume (see Chapters 2 and 3 ).

My definition differs in a number of respects from competing conceptions:

- It accords more emphasis than most others to cultural-cognitive elements - shared beliefs, assumptions, organizing templates, schema. 
The importance of ideas - in contrast to interests or obligations - is an important theme flowing through the chapters of the current volume.

- It emphasizes that institutions are multifaceted structures, highlighting the role of symbolic elements, but insisting that they are only significant to the extent that they are connected to and reflected in social activities, social relations and material resources.

- It stresses the presence and interdependence of three different elements or components - regulative, normative and cultural-cognitive distinguished because they:

- provide differing bases of meaning and order

- are associated with differing social logics

- rely on differing mechanisms

- are identified by different indicators

- conjure up differing aspects of legitimacy (see Table 3.1).

- It recognizes that particular institutional complexes rely more on some elements than others and/or exhibit variation over time in the prominence or salience of the elements (see Hoffman, 1997).

- And, borrowing from Giddens' $(1979,1984)$ structuration theory, it recognizes that institutions operate simultaneously to channel and constrain some structures and behaviors, but also to support and empower others.

Many of the disputes about institutions among analysts stem from their varying attention to one as opposed to another institutional element. Those stressing regulative elements - primarily economists and rational-choice political scientists - give more attention to deliberation and design. Regulative elements are more formalized, more explicit, more easily planned and strategically crafted. Emphasis is placed on clear rules and directives, the manipulation of incentives, and the importance of surveillance (for example, North, 1990; Williamson, 1975, 1985). However, although rules and sanctions are more readily manipulated and their effects more rapid, they can also be superficial and fleeting (Roland, 2004). Actors are more likely to 'game' the system, so that behavior becomes decoupled from rules and formal structure, in a manner depicted by Meyer and Rowan (1977). Unless supported by other elements, a reliance on rules is likely to result in shallow conformity and brittle stability.

Analysts focusing primarily on normative elements - typically sociologists and historical or normative institutionalists in political science - give more attention to the social embeddedness of social and economic behavior (Granovetter, 1985; Peters, 1999: chap. 2). Actors are not viewed primarily as rational calculators but as social persons who care deeply about 
their relationships to others and to their own commitments - their identities. Behavioral norms are reinforced by the response of others but are also internalized by the actor. Much behavior is responsive not to 'instrumental' logics, but to the logic of 'appropriateness' (March and Olsen, 1989). Informal relations among actors and specific situational demands often trump narrowly defined self-interest or utilitarian concerns.

Those stressing cultural-cognitive elements - primarily cultural anthropologists and sociologists and organization theorists - tap into a deeper layer that includes widely shared beliefs about the nature of the world (cultural frames) and cause-effect relations (social logics). The beliefs are 'cultural' because they are socially constructed symbolic representations; they are 'cognitive' because they provide vital templates for framing individual perceptions and decisions. They supply 'the software of the mind' (Hofstede, 1991) that grounds our 'rational' choices. Some of these beliefs and logics are explicit and subject to conscious manipulation - culture as 'tool-kit' (Swidler, 1986) - but others are deeply entrenched - culture as 'taken-for-granted conceptions' of the world (Berger and Luckmann, 1967). The latter, necessarily, are not quickly changed. ${ }^{3}$

\section{INSTITUTIONAL CHANGE}

Social scientists have long been interested in institutions as fundamental sources of social order and stability, but in recent decades increasing attention has been devoted to the causes of institutional change. Early on, it was presumed that, for institutions to change, they must be destabilized by external shocks - by forces of nature, wars, economic jolts or break-through new technologies. Such forces are, of course, at work. But, further reflection has persuaded most scholars that it is overly simplistic to focus entirely or even primarily on external factors: that much institutional change is generated by endogenous forces. Several theoretical developments have guided this recognition.

First, Giddens' $(1979,1984)$ seminal work on structuration theory has reminded us that all social structures - including institutional structures are constructed by social actors. ${ }^{4}$ Social structure is both the context for and the product of action. All social action takes place within and is supported and constrained by existing structures; and all action either reproduces these structures or introduces change into them. The ability to introduce new elements into existing structures is termed 'agency' (DiMaggio, 1988; Emirbayer and Mische, 1998). The actors involved may be individual or collective. Oliver (1991) was among the first to point out that organizations may choose to respond to institutional forces in a variety of ways, not only 
by compliance but by the strategic use of compromise, manipulation and defiance. Institutional forces sometimes proceed in a 'top-down' manner, as superordinate systems attempt to impose conformity on lower-level units, but as often involve a 'bottom-up' process, in which individuals or organizations resist or challenge such efforts, introducing new schemas and logics into the mix of available elements (Scott, 2001: chap. 8). Institutional forces are not one-way and determinate but interactive and reciprocal processes.

Second, institutions are not monolithic, unified systems. Working at a macro level, Friedland and Alford (1991: 232) point out that the institutions that comprise societies 'are potentially contradictory and hence make multiple logics available to individuals and organizations. Individuals and organizations transform the institutional relations of society by exploiting these contradictions.' Thus, for example, the varying beliefs and norms associated with kinship systems often conflict with those governing economic activities; and economic logics often privilege different interests or values than do political logics (for example, efficiency vs equity). But even within a single institutional complex - at a sector or organizational field level - tensions and contradictions are likely to exist due to:

- the existence of entropy: the erosion over time of order, structure, commitments (Zucker, 1988)

- the divide between general principles and local conditions, a 'gap or "mismatch" between the micro and macro levels' (Sjöstrand, 1995: 20)

- the misalignment of institutional elements - rules, norms, beliefs such that significant individuals or organizations are guided by attention to one rather than another element (Scott, 2001: chap. 8).

Third, the new institutionalism, more than alternative perspectives, recognizes the important independent role played by ideas in social life. John Maynard Keynes, the eminent economist, recognized this truth. In the final paragraph of his book on The General Theory he wrote:

The ideas of economists and political philosophers, both when they are right and when they are wrong, are more powerful than is commonly understood. Indeed, the world is ruled by little else. Practical men, who believe themselves to be quite exempt from any intellectual influences, are usually the slaves of some defunct economist. (Keynes, 1973 [1936]: 383)

Those who attempt to explain or guide institutional change - scholars and policy advocates - typically privilege interests. Ideas are distinct from interests, although they serve to ground and frame them. Campbell (2004: chap. 4) elaborates on the different ways in which ideas enter into decision 
making about social change. Among the most important ideas are those providing taken-for-granted assumptions that rest in the deep background of decision processes: broadly shared norms and public sentiments such as national cultures and cognitive paradigms that guide and constrain choice. Operating more in the foreground are the cultural frames that are employed to justify and legitimate decisions, as well as the programs that provide specific guidelines for addressing problems. Types of actors who carry on this work range from theorists and professionals to framing specialists, such as politicians, campaign managers and spin doctors; carriers, such as media representatives and consultants; and brokers - intermediaries who connect the varying social worlds of discourse.

It is increasingly recognized that, as ideas are transmitted from one context to another, they are not simply 'diffused' but 'edited' and 'translated' (Czarniawska and Joerges, 1996; Sahlin-Andersson, 1996; Westney, 1987). As Strang and Meyer (1993: 104, 106) observe, if practices and structures are to diffuse, they must be theorized. 'By theorization, we mean both the development and specification of abstract categories, and the formulation of patterned relationships such as chains of cause and effect ... Under these conditions, we suppose that what flows is rarely an exact copy of some practice existing elsewhere.'

Moreover, there is a wide range of mechanisms or 'carriers' by which ideas are transmitted. I have suggested that carriers may, variously, be comprised of symbolic systems, such as those transmitted by the mass media, relational systems, including interactions among individual and collective actors, by contacts among as well as by the movements of people, routines, such as protocols and standard operating procedures, and artifacts, including tools and technologies (Scott, 2001: chap. 4, 2003). We must recognize that carriers are not neutral conveyers. As Abernethy (2000) has demonstrated, it makes a palpable difference in the international arena whether new ideas favored by foreign countries arrive backed by the bayonets of invading armies, the inducements of merchant traders or the blessings of missionaries.

\section{SOCIAL INNOVATION}

The editors and authors of this volume direct primary attention to the difficult and fundamental question of what role institutions play in the production of new ideas and new kinds of social structures - social innovation. Institutional scholars generally are roughly organized into two camps on this question and, not unexpectedly, these disagreements are reflected in the following chapters. One view, termed 'a positive theory of institutions' 
(DiMaggio and Powell, 1991: 5-6) or 'actor-centered functionalism' (Pierson, 2004: 104), is based primarily on the work of rational-choice economists and political scientists (for example, Moe, 1984; Williamson, 1981). These scholars begin with a conception of boundedly rational, utility-maximizing actors but recognize that choice and behavior take place within the context of institutions. Emphasis is placed on the regulative aspects of institutions: institutions are rule systems that constrain action through the use of incentives - rewards and sanctions. In this approach it is argued that actors construct a particular institution with the expectation that it will serve the interests of those enacting it. Thus, intentionality is closely linked to questions of power.

Rational-choice institutionalists have provided explanations for a wide variety of institutions, ranging from the fabrication of incentive and control systems within organizations and parliaments to the crafting of regulatory policies for sectors to the construction of national and international regimes (see, for example, Shepsle, 1989; Williamson, 1985; Young, 1986). This work provides a strong foundation for rigorous theorizing and has surely served to call the attention of economists and political scientists to the important role played by institutional frameworks in economic and political change. However, it is also rendered vulnerable by its questionable assumptions, many of which are highlighted in Paul Pierson's thoughtful critique of the limits of institutional design (2004: chap. 4). In brief summary, Pierson points out that:

Actors may be instrumental and farsighted but have such multiple and diverse goals that institutional functioning cannot easily be derived from the preferences of designers. Alternatively, actors may not be instrumental in the sense implied by this framework. Or they may be instrumental, but not farsighted. Perhaps, most important, they may in fact have a single, instrumental goal and be farsighted, but major institutional effects may be unintended. Finally, actors may make rational design choices, but change in broader social environments and/or in the character of these actors themselves [for example, their preferences] may markedly worsen the fit between actors and institutional arrangement after they are chosen. (2004: 108)

The second view of institutional construction - one that accords with my own - is primarily associated with sociological and organizational scholars. It emphasizes limitations on the rationality of actors and, hence, of institutional 'design'. This view is less easily summarized because it is less taut, more complex and somewhat messy. It shifts emphasis from the regulative to the normative and cultural-cognitive facets of institutions. Institutions do constrain but they also constitute - both actors and actions. That is, institutional norms and beliefs serve as the basis for constructing models of certain kinds of individual actors - capitalists, entrepreneurs, politicians - or collective 
actors - guilds, churches, corporations - each associated with specific types of actions.

Institutionalized rules, located in the legal, social scientific, customary, linguistic, epistemological, and other 'cultural' foundations of society, render the relation between actors and action more socially tautological than causal. Actors enact as much as they act: What they do is inherent in the social definition of the actor itself. (Meyer et al., 1987: 22)

What is retrospectively viewed as 'rational choice' is often neither rational nor choice but the enactment of an existing script - or perhaps a selection from alternative scripts - called out by who the actor is (her role or identity) and the demands of the situation.

Thus, in attempting to understand the sources of innovation and social creativity, rather than searching for distinctive individual characteristics, many contemporary students of entrepreneurship instead stress the importance of context. The term 'entrepreneurship' conveys too much intentionality and individuality to sit well with dyed-in-the-wool sociological institutionalists, but if understood not as a trait but as a set of activities or efforts that promotes change it can be accommodated into our discourse. Necessarily, actors have a greater capacity for choice and for 'creativity' the more complex and contradictory the institutional matrices in which they are involved. The more contradictions, the more materials - alternative structural templates, routines, scripts - which will be available for actors to deploy. This is one of the ways in which institutions act not just to constrain but to empower actors.

Suchman and colleagues (2001) identify three distinct cultural processes diffusion, recombination and sense-making - associated with entrepreneurship.

Diffusion introduces preexisting models into new fields . . . In this process, entrepreneurship may simply involve imitating the organizational forms of one field when launching new endeavors in another. Recombination goes one step further, constructing novel organizations, but from preexisting standardized components . . . Finally, sensemaking, the most radical form of instructional entrepreneurship, involves the construction of genuinely novel cultural accounts to address unexpected and anomalous events. (2001: 355)

Note that the first two processes involve the enactment of existing models not the generation of new ones - albeit applied to new circumstances or in new combinations. As Meyer and Rowan (1977: 45) point out: In contemporary societies, 'the building blocks for organizations [are] littered around the societal landscape; it takes only a little entrepreneurial energy to assemble them into a structure'. 
More generally, the empirical research of many scholars supports the conclusion that 'entrepreneurship is a collective activity' (Schoonhoven and Romanelli, 2001: 387). Rather than the efforts of lone individuals, it is more often teams of individuals who work collectively to create new organizations; 'founding teams tend to be formed from among existing networks of colleagues' (p. 386). And such teams are 'even more critical to the founding of new industries or [new] organizational populations' (p. 386). Only collective efforts can combine to create the necessary regulatory, normative and cultural-cognitive supports to sustain a new industry or field (Aldrich and Fiol, 1994).

As is well known, once established, institutional frameworks are likely to persist. As particular patterns - political, economic, industrial - are laid down, later developments are likely to follow along in the same contours in what is termed a 'path dependent' process (David, 2000). Because different societies have developed under varying conditions and at varying rates, each shows a somewhat distinctive complex of institutional arrangements. This 'matrix of institutions' constitutes and defines the 'innovative capabilities of a nation' (Murmann and Tushman, 2001: 181; see also Nelson, 1993).

A debate currently rages among globalization scholars regarding the long-term effects of the processes at work. ${ }^{5}$ Some argue that it produces increasing convergence among nations and organizational forms, such as corporations. Neo-liberal economists and political scientists assert that the competitive forces unleashed by finance capitalism press these structures to adopt the most productive and efficient (hence, similar) arrangements (see McKenzie and Lee, 1991; Ohmae, 1990). And some institutional scholars, such as John Meyer and associates, have described and documented the homogenizing effects of culturally defined frameworks of 'rationalization' that conduce states and companies to embrace at least superficially similar structures (Drori et al., 2006; Meyer and Hannan, 1979).

However, a substantial number of other scholars, including many institutionalists, insist that divergence - the persistence and reinforcement of difference - is both the expected and the observed outcome of globalization. They point to continuing fundamental differences in the socioeconomic structure of states and societies (Hall and Soskice, 2001), to continuing differences in the policy culture of states (Dobbin, 1994), to differences in assumptions regarding economic organization and differing 'recipes' for constructing business systems (Orrù, Biggart and Hamilton, 1997; Whitley, 1992) and to differing strategic reactions by various countries and their industries to the 'same' global competitive pressure (Guillén, $2001 \mathrm{~b}$ ). The debate regarding the effects of globalization processes on states and organizations is far from settled - indeed, the processes themselves are 
still under way, but it seems fair to conclude that most of the contributors to this volume see more evidence of divergence than convergence among industries and countries.

A final observation. Although the focus of the current volume is on institutional change taking place within countries, it is important that we do not overlook the institution-building activities taking place at the transnational level. During the current era, an ever-increasing number and variety of institutional agents are at work constructing new rules, new norms and new schemas. The types of agents include multi-national consulting organizations; professional associations engaged in efforts to reform and standardize practices within every area of social life - from child care to environmental protections, to quality assurance within companies, to international advocacy groups, such as Advocacy International and Earthfirst; and framers and arbiters of international trade agreements (see Boli and Thomas, 1999; Brunsson and Jacobsson, 2000; Smith, 2005; Young, 1986). These and related actors and processes may be expected to strongly affect economic development processes now under way within individual societies. We embrace the conclusion reached by Djelic and Quack:

From the perspective we adopt that any kind of economic activity is embedded in a wider institutional frame, this is also true of transnational markets in the larger sense of the word. Hence we argue that globalization of economic activity reveals ... processes of institutionalization in the transnational space. Globalization, we claim, is not only about adaptation and change of national institutions. It is also about institution building in the transnational arena - a space traditionally and typically pictured and described as anomic and adversarial. (2003: 3)

In our time, there is much to look at and much to see by employing an institutional lens, as readers of this volume will discover as they peruse the chapters of this book.

\section{NOTES}

1. There exist, of course, quite important precursor studies, such as those of Weber (1968 trans. [1924]), Geertz (1963) and Dore (1973).

2. As Swiss historian and economist Simonde de Sismondi (1837: iv) observed nearly two centuries ago: 'I am convinced that one falls into serious error in wishing always to generalize everything connected with the social sciences. It is on the contrary essential to study human conditions in detail. One must get hold now of a period, now of a country, now of a profession, in order to see clearly what a man is and how institutions act upon him.'

3. For a more extensive discussion of institutional elements, see Scott (2001), Chapters 3 and 4 . 
4. Giddens (1984: 24) defines institutions as 'the more enduring features of social life ... giving "solidity" [to social systems] across time and space'.

5. For thoughtful summary discussions, see Guillén (2001a) and Campbell (2004: chap. 5).

\section{REFERENCES}

Abernethy, David B. (2000), The Dynamics of Global Dominance: European Overseas Empires, 1415-1980, New Haven, CT: Yale University Press.

Aldrich, Howard E. and C. Marlene Fiol (1994), 'Fools rush in? The institutional context of industry construction', Academy of Management Review, 19, 654-70.

Berger, Peter L. and Thomas Luckmann (1967), The Social Construction of Reality, New York: Doubleday Anchor.

Boli, John and George M. Thomas (ed.) (1999), Constructing World Culture: International Nongovernmental Organizations since 1874, Stanford, CA: Stanford University Press.

Bourdieu, Pierre and Loic Wacquant (1992), An Invitation to Reflexive Sociology, Chicago: University of Chicago Press.

Brunsson, Nils and Bengt Jacobsson (eds) (2000), A World of Standards, Oxford, UK: Oxford University Press.

Campbell, John L. (2004), Institutional Change and Globalization, Princeton, NJ: Princeton University Press.

Czarniawska, Barbara and B. Joerges (1996), 'Travels of ideas', in Barbara Czarniawska and G. Sevón (eds), Translating Organizational Change, Berlin: Walter de Gruyter, pp. 13-48.

David, Paul (2000), 'Path dependence, its critics, and the quest for "historical economics"', in P. Garrouste and S. Ioannides (eds), Evolution and Path Dependence in Economic Ideas: Past and Present, Cheltenham, UK and Northampton, MA, USA: Edward Elgar.

DiMaggio, Paul J. (1988), 'Interest and agency in institutional theory', in Lynn G. Zucker (ed.), Institutional Patterns and Organizations: Culture and Environment, Cambridge, MA: Ballinger, pp. 3-20.

DiMaggio, Paul J. and Walter W. Powell (1983), 'The iron cage revisited: Institutional isomorphism and collective rationality in organizational fields', American Sociological Review, 48, 147-60.

DiMaggio, Paul J. and Walter W. Powell (1991), 'Introduction', in Walter W. Powell and Paul J. DiMaggio (ed), The New Institutionalism in Organizational Analysis, Chicago: University of Chicago Press, pp. 1-38.

Djelic, Marie-Laure and Sigrid Quack (2003), 'Introduction: Governing globalization - bringing institutions back in', in Marie-Laure Djelic and Sigrid Quack (eds), Globalization and Institutions: Redefining the Rules of the Economic Game, Cheltenham, UK and Northampton, MA, USA: Edward Elgar, pp. 1-14.

Dobbin, Frank (1994), Forging Industrial Policy: The United States, Britain, and France in the Railway Age, New York: Cambridge University Press.

Dore, Ronald (1973), British Factory, Japanese Factory: The Origins of National Diversity in Industrial Relations, Berkeley, CA: University of California Press.

Drori, Gili S., John W. Meyer and Hokyu Hwang (eds) (2006), Globalization and Organization: World Society and Organizational Change, New York: Oxford University Press. 
Emirbayer, Mustafa and Ann Mische (1998), 'What is agency?', American Journal of Sociology, 103, 281-317.

Evans, Peter B. (1979), Dependent Development, Princeton, NJ: Princeton University Press.

Friedland, Roger and Robert R. Alford (1991), 'Bringing society back in: Symbols, practices, and institutional contradictions', in Walter W. Powell and Paul J. DiMaggio (eds), The New Institutionalism in Organizational Analysis, Chicago: University of Chicago Press, pp. 232-63.

Geertz, Clifford (1963), Peddlers and Princes: Social Development and Economic Change in Two Indonesian Towns, Chicago: University of Chicago Press.

Gerschenkron, Alexander (1962), Economic Backwardness in Historical Perspective, Cambridge, MA: Harvard University Press.

Giddens, Anthony (1979), Central Problems in Social Theory, Berkeley: University of California Press.

Giddens, Anthony (1984), The Constitution of Society, Berkeley: University of California Press.

Granovetter, Mark (1985), 'Economic action and social structure: The problem of embeddedness', American Journal of Sociology, 91, 481-510.

Guillén, Mauro F. (2001a), 'Is globalization civilizing, destructive or feeble? A critique of five key debates in the social science literature', Annual Review of Sociology, 27, 235-60.

Guillén, Mauro F. (2001b), The Limits of Convergence: Globalization and Organizational Change in Argentina, South Korea, and Spain, Princeton, NJ: Princeton University Press.

Hall, Peter A. (1986), Governing the Economy: The Politics of State Intervention in Britain and France, New York: Oxford University Press.

Hall, Peter A. and David Soskice (eds) (2001), Varieties of Capitalism, New York: Oxford University Press.

Hoffman, Andrew W. (1997), From Heresy to Dogma: An Institutional History of Corporate Environmentalism, San Francisco: New Lexington Press.

Hofstede, Geert (1991), Cultures and Organizations: Software of the Mind, New York: McGraw-Hill.

Keynes, John Maynard (1973 [1936]), The General Theory of Employment, Interest and Money, London: Macmillan.

Leff, Nathaniel (1978), 'Industrial organization and entrepreneurship in developing countries: The economic groups', Economic Development and Cultural Change, 26, 661-75.

McKenzie, Richard B. and Dwight R. Lee (1991), Quicksilver Capital, New York: Free Press.

March, James G. and Johan P. Olsen (1984), 'The new institutionalism: Organizational factors in political life', American Political Science Review, 78, 437-49.

March, James G. and Johan P. Olsen (1989), Rediscovering Institutions: The Organizational Basis of Politics, New York: Free Press.

Meyer, John W. and Michael T. Hannan (eds) (1979), National Development and the World System: Educational, Economic, and Political Change, 1950-1970, Chicago: University of Chicago Press.

Meyer, John W. and Brian Rowan (1977), 'Institutionalized organizations: Formal structure as myth and ceremony', American Journal of Sociology, 83, 340-63.

Meyer, John W. and W. Richard Scott (1983), Organizational Environments: Ritual and Rationality, Beverly Hills, CA: Sage. 
Meyer, John W., John Boli and George M. Thomas (1987), 'Ontology and rationalization in the Western cultural account', in George M. Thomas, John W. Meyer, Francisco O. Ramirez and John Boli (eds), Institutional Structure: Constituting State, Society, and the Individual, Newbury Park, CA: Sage, pp. 12-37.

Moe, Terry (1984), 'The new economics of organization', American Journal of Political Science, 28, 739-77.

Murmann, Johann Peter and Michael L. Tushman (2001), 'From the technology cycle to the entrepreneurship dynamic', in Claudia Bird Schoonhoven and Elaine Romanelli (eds), The Entrepreneurship Dynamic: The Origins of Entrepreneurship and its Role in Industry Evolution, Stanford, CA: Stanford University Press, pp. $178-203$.

Nee, Victor (2005), 'The new institutionalisms in economics and sociology', in Neil J. Smelser and Richard Swedberg (eds), The Handbook of Economic Sociology, 2nd edn, Princeton, NJ and New York: Princeton University Press and Russell Sage Foundation, pp. 49-74.

Nelson, Richard R. (ed.) (1993), National Innovation Systems, New York: Oxford University Press.

North, Douglass (1990), Institutions, Institutional Change, and Economic Performance, Cambridge: Cambridge University Press.

North, Douglass (2005), Understanding the Process of Economic Change, Princeton, NJ: Princeton University Press.

Ohmae, Kenichi (1990), The Borderless World: Power and Strategy in the Interlinked Economy, New York: Harper Collins.

Oliver, Christine (1991), 'Strategic responses to institutional processes', Academy of Management Review, 16, 145-79.

Orrù, Mauro, Nicole Woolsey Biggart and Gary G. Hamilton (1997), The Economic Organization of East Asian Capitalism, Thousand Oaks, CA: Sage.

Ostrom, Eleanor (1990), Governing the Commons: The Evolution of Institutions for Collective Action, Cambridge: Cambridge University Press.

Peters, B. Guy (1999), Institutional Theory in Political Science: The 'New Institutionalism', London: Pinter.

Pierson, Paul (2004), Politics in Time: History, Institutions and Social Analysis, Princeton, NJ: Princeton University Press.

Roland, Gérard (2004), 'Understanding institutional change: Fast-moving and slowmoving institutions', Studies in Comparative International Development, 38, 109-31.

Rostow, Walt W. (1960), The Stages of Economic Growth: A Non-Communist Manifesto, Cambridge: Cambridge University Press.

Sahlin-Andersson, Karen (1996), 'Imitating by editing success: The construction of organizational fields', in Barbara Czarniawska and G. Sevón (eds), Translating Organizational Change, Berlin: Walter de Gruyter, pp. 69-92.

Schoonhoven, Claudia Bird and Elaine Romanelli (2001), 'Emergent themes and the next wave of entrepreneurial research', in Claudia Bird Schoonhoven and Elaine Romanelli (eds), The Entrepreneurship Dynamic: Origins of Entrepreneurship and the Evolution of Industries, Stanford, CA: Stanford University Press, pp. 383-408.

Scott, W. Richard (2001), Institutions and Organizations, 2nd edn, Thousand Oaks, CA: Sage.

Scott, W. Richard (2003), 'Institutional carriers: Reviewing modes of transporting ideas over time and space and considering their consequence', Industrial and Corporate Change, 12, 879-94. 
Scott, W. Richard (forthcoming), 'The maturation of institutional theory', Theory and Society.

Shepsle, Kenneth A. (1989), 'Studying institutions: Some lessons from the rational choice approach', Journal of Theoretical Politics, 1, 131-47.

Simonde de Sismondi, J.C.L. (1837), Études sur l'économie politique, Vol. 1, Paris: Treuttel et Würtz.

Sjöstrand, Sven-Erik (1995), 'Toward a theory of institutional change', in John Groenewegen, Christos Pitelis and Sven-Erik Sjöstrand (eds), On Economic Institutions: Theory and Applications, Aldershot, UK and Brookfield, US: Edward Elgar, pp. 19-44.

Smith, Jackie (2005), 'Globalization and transnational social movement organizations', in Gerald F. Davis, Doug McAdam, W. Richard Scott and Mayer N. Zald (eds), Social Movements and Organization Theory, New York: Cambridge University Press, pp. 226-48.

Strang, David and John W. Meyer (1993), 'Institutional conditions for diffusion', Theory and Society, 22, 487-511.

Suchman, Mark C., Daviel J. Steward and Clifford A. Westfall (2001), 'The legal environment of entrepreneurship', in Claudia Bird Schoonhoven and Elaine Romanelli (eds), The Entrepreneurship Dynamic: Origins of Entrepreneurship and the Evolution of Industries, Stanford, CA: Stanford University Press, pp. 349-82.

Swidler, Ann (1986), 'Culture in action: Symbols and strategies', American Sociological Review, 51, 273-86.

Wallerstein, Immanuel (1974), The Modern World-System: Capitalist Agriculture and the Origins of the European World-Economy in the Sixteenth Century, New York: Academic Press.

Weber, Max (1968 trans. [1924]), Economy and Society: An Intrepretive Sociology, 2 vols, ed. Guenther Roth and Claus Wittich. New York: Bedminister Press.

Westney, D. Eleanor (1987), Imitation and Innovation: The Transfer of Western Organizational Patterns to Meiji Japan, Cambridge, MA: Harvard University Press.

Whitley, Richard (1992), 'The social construction of organizations and markets: The comparative analysis of business recipes', in Michael Reed and Michael Hughes (eds), Rethinking Organizations: New Directions in Organization Theory and Analysis, Newbury Park, CA: Sage, pp. 120-43.

Williamson, Oliver (1975), Markets and Hierarchies, New York: Free Press.

Williamson, Oliver (1981), 'The economics of organizations: The transactions cost approach', American Journal of Sociology, 87, 548-77.

Williamson, Oliver (1985), The Economic Institutions of Capitalism, New York: Free Press.

Young, Oren R. (1986), 'International regimes: Toward a new theory of Institutions', World Politics, 39, 104-22.

Zucker, Lynn G. (1988), 'Where do institutional patterns come from? Organizations as actors in social systems', Institutional Patterns and Organizations: Culture and Environment, Cambridge, MA: Ballinger, pp. 23-49. 
W. Richard Scott - 9781847206992 Downloaded from PubFactory at 04/26/2023 02:52:54AM via free access 